\title{
\#14
}

\section{Menyoal Kode Etik Jurnalisme Era Disrupsi}

Sunarto, Nurul Hasfi, \& Amida Yusriana

Perkembangan teknologi dewasa ini telah menghadirkan era disrupsi bagi banyak aspek kehidupan. Salah satunya aspek komunikasi. Sekarang ini semakin banyak dijumpai informasi bohong dan fitnah (hoax) beredar di jagad maya kita. Sebagaimana dilaporkan oleh Detik.com (Azzahra, 2021), terdapat sebanyak 352 kasus terkait hoaks tentang Covid-19 di media elektronik dan media sosial yang menjadi urusan pihak kepolisian. Sedang Rakyat Merdeka (Asi, 2021) melaporkan, Kementerian Komunikasi dan Informasi (Kemenkominfo) sejak 23 Januari 2020 hingga 1 Februari 2021 menemukan 1.402 kasus hoaks terkait Covid-19 dan 97 kasus terkait vaksin.

Selain hoaks, era disrupsi ini juga ditandai dengan meredupnya kehidupan bisnis media konvensional (sunset industry). Ekosistem media yang berubah sekarang ini menjadikan media konvensional harus bekerja keras untuk dapat bertahan. Kode etik jurnalistik 
menjadi andalan pengelola media konvensional dalam era disrupsi untuk melawan gempuran informasi melalui jurnalisme pribadi (personal journalism) di media sosial. Setidaknya demikianlah yang diyakini oleh salah seorang narasumber dalam penelitian berjudul Monograp Esensi Kepemimpinan Jurnalis Wanita di Media Pada Era 4.0. (Sunarto, Nurul, dan Amida, 2020).

Menurut narasumber di atas, dalam kondisi perkembangan teknologi yang luar biasa masif sekarang ini, media konvensional akan kalah bersaing dengan media baru semacam WhatApps atau media sosial yang lain apabila menjual kecepatan ataupun kedalaman informasi yang disajikan. Hal itu disebabkan para Youtuber sudah dapat melakukan itu semua sebagai jurnalis pribadi.

Selain itu seorang narasumber dalam posisi sebagai Wakil Pemimpin Redaksi sebuah koran lokal terkait strategi yang dijalankannya menghadapi era disrupsi ini mengungkapkan pula "Tapi, kita meyakini, bahwa media kami ini adalah sebuah institusi pers dan kami punya kode etik. Itu menjadi salah satu senjata utama kami, bahwa apa yang kami hadirkan ini benar-benar bisa dipertanggungjawabkan. Kami beda dengan Youtuber-youtuber yang mengais informasi dengan mengambil narasumbernarasumber yang kontroversial. Kemudian mereka tidak diikat dengan kode etik," (Sunarto, Nurul, dan Amida, 2020).

Narasumber tersebut sangat menanamkan pada anak buahnya akan arti penting menggunakan kode etik sebagai senjata ampuh melawan jurnalisme pribadi yang dilakukan oleh para Youtuber dan penggiat media sosial yang lain."Berita-berita yang kami hadirkan adalah berita-berita yang bisa menjadi rujukan informasi dan bisa kami pertanggungjawabkan dalam kode etik. Karena kalau ada kesalahan, kami harus berhadapan dengan Dewan Pers," tegas narasumber tersebut untuk menjaga dan mempertahankan semangat kerja anak buahnya. 
Bagi praktisi media, tampaknya kembali kepada kode etik profesi jurnalis dapat menjadi kunci strategis untuk mengatasi kompetisi dan meluasnya informasi hoaks di media sosial dalam era disrupsi sekarang ini. Terkait dengan gagasan tentang kode etik profesi maka artikel ini mencoba untuk mengelaborasi gagasan tersebut.

\section{Media Era Disrupsi}

Saat ini kita hidup dalam era Revolusi Industri 4.0. Era ini ditandai dengan perkembangan teknologi digital secara masif sehingga menimbulkan disrupsi pada banyak aspek kehidupan. Menurut Schwab (2019) konvergensi antara aspek fisik, digital dan biologi yang menjadi ciri utama Era 4.0 ini memberikan kesempatan luas bagi dunia industri untuk melakukan aktivitas berbasis sumber daya teknologi secara efektif dan efisien untuk menciptakan model bisnis yang lebih produktif, regeneratif dan restoratif.

Industri media massa salah satunya yang terimbas disrupsi teknologi tersebut. Sekarang ini keberadaan media konvensional (surat kabar, majalah, televisi, radio, film) beriringan dengan media baru (media sosial, media online). Menurut Steele (2014), teknologi untuk mengumpulkan, memproses dan menyampaikan berita berkembang sangat cepat dalam menciptakan berbagai kemungkinan dinamis, tetapi terlalu sering memproduksi liputan distortif dengan kualitas rendah. Dalam periode adaptasi intensif sekarang ini, jurnalis dan jajaran eksekutif berita menggunakan alatalat digital dan menciptakan isi inovatif dengan beragam tingkat ketertarikan yang dapat berisi ketakutan, keahlian maupun kebodohan.

Sekarang ini kebutuhan informasi, hasrat dan perilaku publik juga berubah secara dramatis. Para praktisi jurnalisme harus memberikan perhatian pada apa yang didiktekan oleh pasar dan apa yang dibutuhkan oleh konsumen karena mereka juga 
berpartisipasi dalam penciptaan dan pendistribusian produk jurnalisme. Tetapi, ada bahaya di sini, ketika praktek jurnalisme itu tergantung secara intensif pada jaringan sosial dan algoritme untuk menyampaikan informasi penting. Praktek jurnalisme yang selama ini mengandalkan akurasi, adil, substantif dan krusial dapat tergerus oleh penggunaan teknologi algoritme tersebut.

Perkembangan teknologi sekarang ini dapat melemahkan upaya jurnalis untuk mengejar kebenaran dalam pemberitaan mereka. Munculnya budaya media gabungan (mixed media culture) telah menggeser fungsi jurnalisme klasik untuk menyajikan laporan yang benar dan dapat diandalkan. Budaya baru ini menciptakan jurnalisme baru yang berisi percakapan yang mengalahkan jurnalisme lama yang bersandar pada verifikasi. Pada abad baru ini kebutuhan untuk kebenaran semakin besar, bukan berkurang. Hal tersebut disebabkan sekarang ini ketidakbenaran semakin menjadi lazim (Kovach dan Rosenstiel, 2004).

\section{Arti Penting Jurnalisme di Era Disrupsi}

Dalam masa yang dipenuhi kelaziman ketidakbenaran, kebutuhan akan jurnalisme berkualitas menjadi tidak terelakkan. Sebagaimana dilaporkan Liputan6.Com (Widjaya, 2018), di Indonesia terdapat sekitar 47.000 media dengan porsi terbesar media daring yaitu sebanyak 43.300 media. Dari jumlah media daring yang ada, hanya 168 media yang telah terdata di Dewan Pers. Sisanya tidak. Sehingga, masyarakat harus berhati-hati untuk mengonsumsi informasi dari media daring yang belum terverifikasi ini.

Keberadaan jurnalisme, sebagaimana dijelaskan oleh Bon Steele (2014), mempunyai peran khusus di masyarakat. Jurnalisme hadir untuk melayani kebutuhan publik tidak seperti bisnis atau profesi yang lain. Jurnalisme mempunyai kewajiban untuk mendukung proses yang demokratis melalui informasi dan pendidikan. Jurnalisme mempunyai tanggung jawab untuk memberikan warga 
negara informasi yang bermakna sehingga mereka bisa mempunyai pemahaman yang lebih baik terkait isu-isu yang ada di komunitas mereka. Selain itu agar mereka dapat menjalani dan membuat keputusan yang baik untuk kehidupan sehari-hari mereka serta melaksanakan secara efektif kewajiban mereka sebagai warna negara.

Jurnalisme adalah sebuah temuan atau sebuah bentuk dari ekspresi yang digunakan media massa untuk melaporkan dan mengomentari peristiwa-peristiwa dan gagasan-gagasan yang ada di sini dan sekarang (Adam, 2006). Menurut Adam, terdapat 5 (lima) elemen penting dalam definisi tersebut, yaitu: (1) sebuah bentuk ekspresi yang merupakan sebuah temuan; (2) laporan gagasangagasan dan peristiwa-peristiwa; (3) komentar pada gagasan dan peristiwa; (4) sirkulasi publik dari gagasan dan peristiwa; dan (5) di sini dan sekarang.

Elemen pertama terkait ekspresi yang menjadi temuan. Dalam pengertian yang paling mendasar, kegiatan jurnalistik terkait pelaporan peristiwa dan gagasan sebagaimana terjadi melalui kegiatan koleksi dan presentasi informasi pada subjek yang mengalami peristiwa atau mempunyai gagasan tertentu. Pelaporan bencana alam, perkembangan korban pandemi atau pendapat pakar terkait hal tersebut yang hari-hari ini menghiasai media di tanah air merupakan contoh bagaimana kegiatan jurnalistik tersebut berlangsung.

Selain melaporkan apa yang terjadi, kegiatan jurnalistik juga melibatkan kritik, penjelasan, atau pengiriman penilaian pada pembentukan segala sesuatu. Setiap unsur dalam penemuan yang sedang berlangsung ini, dimana ada hal-hal yang dilakukan secara sadar dan tidak sadar, melibatkan sebuah penilaian atau sebuah evaluasi akan arti penting, nilai, atau harga dari tindakan itu pada subjek-subjeknya. Pelaporan bencana alam, korban pandemic, dan 
pendapat pakar terkait, tidak hanya sekedar peristiwa tapi juga mengandung nilai di dalamnya yang mewakili penilaian kita pada peristiwa tersebut. Dengan demikian, jurnalisme merupakan aplikasi dari nilai yang kita gunakan untuk mengevaluasi segala sesuatu. Nilai ini direfleksikan dalam kegiatan jurnalistik melalui seleksi subjek oleh jurnalis yang mempunyai nilai dalam dirinya mengenai bagaimana seharusnya dunia ini bekerja dengan baik. Dalam pemahaman semacam ini, jurnalisme mencakup dan memberikan sebuah tempat untuk komentar, kritik dan penilaian.

Jurnalisme juga bersifat publik. Terkait hal ini kita harus bisa membedakan dalam pikiran kita suara-suara yang khusus dan bersifat privat dengan suara-suara yang boleh diketahui oleh publik. Jurnalisme sejauh berhubungan dengan aspek kebaruan, kisah, pidato, dan pernyataan singkat diciptakan untuk kepentingan publik. Oleh karena itu, suara dan ragam kata yang digunakan diwarnai oleh tanggung jawab secara didaktik melalui tampilan eksplisit dan ketiadaan kutipan-kutipan yang mempunyai makna dalam ranah privat atau ragam kata yang mempunyai makna hanya dalam wacana khusus semacam ilmu pengetahuan.

Sifat publik jurnalisme juga ditandai dengan hubungannya dengan kekinian dan di sini. Hal itu disebabkan, jurnalisme hanya menampilkan dunia nyata yang masuk dalam kategori kekinian, bukan masa lalu.

Semua elemen yang sudah dijelaskan tersebut - pelaporan (reporting), penilaian (judging), suara publik (public voice), dan kekinian (here and now) - berakumulasi dalam proses penciptaan berdasarkan imajinasi secara individual dan kultural. Jurnalisme merupakan penemuan atau penciptaan imajinatif jurnalis dalam kapasitas sebagai individu dan anggota kelompok kultur tertentu di masyarakat. Meskipun produk jurnalistik merupakan karya jurnalis secara individual, apa yang diekspresikan dalam produk itu merupakan perwujudan bentuk budaya dimana jurnalis itu menjadi 
anggotanya. Artinya, meskipun produk jurnalistik itu merupakan sebuah temuan, tapi bukan merupakan temuan jurnalis tersebut. Jurnalis hanya menyampaikan apa yang ada dalam budaya ini.

Sementara itu, menurut Bill Kovach dan Tom Rosenstiel (2004), tujuan utama jurnalisme adalah menyediakan informasi yang dibutuhkan warga agar mereka bisa hidup merdeka dan mengatur diri sendiri. Misi jurnalisme ini bersama-sama dengan kode etik jurnalisme bertujuan untuk melayani kesejahteraan umum dengan menginformasikan berita kepada orang-orang.

Untuk mencapai tujuan itu, menurut Kovach dan Rosenstiel, kegiatan jurnalistik dilaksanakan dengan memenuhi 9 (sembilan) elemen jurnalisme yang ada, yaitu: (1) kewajiban pertama jurnalisme adalah pada kebenaran; (2) loyalitas pertama jurnalisme kepada warga; (3) intisari jurnalisme adalah disiplin dalam verifikasi; (4) para praktisinya harus menjaga independensi terhadap sumber berita; (5) jurnalisme harus berlaku sebagai pemantau kekuasaan; (6) jurnalisme harus menyediakan forum publik untuk kritik maupun dukungan warga; (7) jurnalisme harus berupaya membuat yang penting menarik dan relevan; (8) jurnalisme harus menjaga agar berita komprehensif dan proporsional; dan (9) para praktisinya harus diperbolehkan mengikuti nurani mereka.

Di antara berbagai elemen tersebut, era disruptif sekarang ini sangat membutuhkan aktualisasi elemen ketiga terkait disiplin verifikasi. Elemen ini terkait dengan objektivitas jurnalis dalam melaporkan informasi kepada publik dengan bersikap tidak berat sebelah (fairness) dan seimbang (balance). Hal ini bisa dicapai ketika jurnalis tidak pernah menambahi sesuatu yang tidak ada, tidak pernah menipu khalayak dan berlaku setransparan mungkin terkait metoda dan motivasi pribadi. Selain itu, jurnalis harus mengandalkan reportase sendiri dan bersikap rendah hati. 
Verifikasi informasi bisa dilakukan jurnalis dengan cara melakukan penyuntingan skeptis, pengecekan akurasi, dan tidak berasumsi. Memberikan tanda pada naskah pra cetak yang masih meragukan dan selalu berhati-hati menggunakan sumber anonim adalah tindakan lain yang bisa dilakukan dalam proses verifikasi informasi. Elemen substantif dalam praktek jurnalistik ini sekarang banyak dicederai dengan maraknya informasi hoaks yang disebarluaskan pihak-pihak tidak bertanggung jawab untuk mencapai tujuan-tujuan pragmatis tertentu melalui kebebasan yang diberikan media sosial. Dalam konteks semacam ini, apa yang telah dilakukan oleh praktisi media, sebagaimana disampaikan di awal artikel ini, untuk menggunakan kode etik jurnalisme sebagai landasan utama dalam menjalankan profesinya sangat bisa dipahami. Hanya dengan menggunakan landasan kode etik jurnalisme inilah kebenaran profesional sebagaimana dimaksudkan oleh Kovach dan Rosenstiel tersebut dapat diaktualisasikan.

Bagaimana kebenaran dalam jurnalisme bisa diperoleh? Kebenaran macam apa yang disampaikan jurnalisme? Fakta yang ditampilkan dalam berita harus akurat dan berimbang. Akurat dipahami sebagai fakta yang benar yaitu adanya kesesuaian antara pernyataan dengan kenyataan (correspondence). Dalam realitanya akurasi ini dapat diperoleh manakala jurnalis menggunakan sumber berita yang dapat dipercaya, meneliti fakta dengan seksama dan menggunakan metoda transparan untuk mendapatkan fakta. Posisi akurasi ini sangat penting karena menjadi fondasi bagi bangunan di atasnya: konteks, interpretasi, debat dan semua hal terkait komunikasi publik.

Sedang keseimbangan (balance) terkait pemberian porsi seimbang pada pihak-pihak terkait dengan objek pemberitaan. Meskipun, keseimbangan ini dapat bersifat subjektif, setidaknya jurnalis dituntut untuk bersikap dan berlaku adil dalam menampilkan pihakpihak terkait dan relevan dalam pemberitaan. 
Secara kongkrit, jurnalisme mengaktualisasikan kebenaran fungsional yang dapat dipraktekkan yaitu sebuah kebenaran yang tidak bersifat mutlak dan filosofis tapi kebenaran yang bisa dijalankan dalam keseharian. Sebuah proses pencarian kebenaran dari hari ke hari secara berkelanjutan untuk mencapai pemahaman. Hal ini dapat terjadi dengan cara jurnalis menulis sebuah berita pada hari pertama yang akan diikuti dengan perkembangan berita yang sama pada hari berikutnya. Begitu seterusnya hingga dirasa fakta dalam berita itu sudah selesai disampaikan.

Kebenaran fungsional semacam itulah yang menjadi acuan profesi jurnalis dalam bekerja sebagai aktualisasi nilai-nilai yang ada dalam kode etik profesi mereka. Sebuah panduan profesional yang harus diikuti jurnalis dalam menjalankan profesi keseharian mereka.

\section{Arti Penting Kode Etik Jurnalistik di Era Disrupsi}

Untuk memahami Kode Etik Jurnalistik, tidak bisa dilepaskan dari pemahaman pada persoalan etika sebagai bagian substantif di dalamnya. Menurut Ward (2009), etika merupakan analisis, evaluasi dan promosi pada apa yang membentuk perilaku baik dan karakter bijaksana sesuai dengan prinsip-prinsip terbaik yang ada. Etika tidak semata-mata bertanya tentang bagaimana kita hidup baik, tetapi bagaimana seharusnya kita hidup baik secara etis dalam kebaikan dan dalam relasi hak dengan orang lain. Etika terkait dengan sebuah tugas yang mempersyaratkan kita untuk melepaskan keuntungan pribadi atau mengalami penderitaan dalam melaksanakan tugas.

Sedang menurut Rolnicki, Tate dan Taylor (2015), etika terkait dengan standar atau aturan perilaku yang didasarkan pada penilaian moral. Etika ini bisa dibedakan menjadi etika pribadi dan profesional. Etika pribadi merupakan standar untuk menjalankan kehidupan sehari-hari yang dipelajari di sekolah, rumah, tempat 
ibadah, teman sebaya dan pemerintah. Standar ini harus ditaati agar orang bisa hidup rukun dalam masyarakat.

Sedang etika profesi terkait dengan standar atau aturan khusus yang harus ditaati oleh anggota profesi. Bagi jurnalis, pedoman etika ini akan membantu mereka dalam proses mencari berita. Etika jurnalisme merefleksikan misi jurnalisme dalam masyarakat, moralitas pribadi, dan beberapa undang-undang media yang ada. Kode etik profesi ini bisa mewujud dalam beragam bentuk. Kode etik ini berupa prinsip-prinsip yang dapat digunakan sebagai panduan tindakan, referensi atau basis bagi dokumentasi tertentu. Bisa juga, berupa kebijakan publik yang didalamnya termasuk aspek-aspek dari perilaku, norma dan praktek yang bisa diterima di kelompok atau masyarakat. Kode etik ini juga dapat dalam bentuk kode tindakan yang mencakup prinsip-prinsip etis atau berupa instrumen legal yang memaksa tindakan baik melalui peradilan. Keberadaan kode etik profesi bisa digunakan untuk pendisiplinan, rekomendasi, pendidikan, inspirasi atau publikasi (Kizza, 2003).

Jurnalisme membutuhkan kode etik disebabkan karena jurnalisme memberi banyak manfaat dalam menjalankan fungsi-fungsi penting dalam masyarakat demokratis, antara lain: (1) jurnalisme memberi informasi publik tentang fakta dan kejadian yang penting bagi masyarakat; (2) jurnalisme menjamin kebebasan aliran informasi yang penting bagi kelahiran dan kelangsungan demokrasi; (3) jurnalisme menyediakan forum untuk pandangan yang beragam; (4) jurnalisme berfungsi sebagai pengawas pemerintah, dan institusi lain untuk memberi tahu publik jika ada tanda-tanda tindakan yang salah; (5) jurnalisme mendukung perubahan demi kepentingan publik; dan (6) jurnalisme mencari kebenaran dengan komitmen yang tegas (Rolnicki, Tate dan Taylor, 2015)

Dengan adanya Kode Etik Jurnalistik, menurut Rolnicki dan kawankawan, profesi jurnalis akan mendapatkan beberapa keuntungan, 
antara lain: (1) kode etik membantu membangun pemahaman profesionalisme bagi mereka yang bekerja untuk satu organisasi berita atau anggota asosiasi berita, dan bagi jurnalis pada umumnya; (2) kepatuhan pada kode etik akan menciptakan kredibilitas di mata pembaca dan pemirsa, serta publik akan percaya pada apa yang ditulis, dilihat dan didengarnya; dan (3) kode etik memberikan ukuran yang seragam untuk mengatasi problem dalam pengumpulan berita.

Sedang menurut Ward (2009), etika jurnalisme merupakan satu jenis aplikasi etika media yang mengkaji persoalan-persoalan "mikro" terkait apa yang seharusnya dilakukan individu jurnalis dalam situasi-situasi tertentu dan persoalan-persoalan "makro" terkait apa yang seharusnya dilakukan oleh media berita dan berperan dalam masyarakat yang ada.

Dalam pandangan Ward, tugas utama etika jurnalisme adalah menentukan bagaimana norma-norma yang ada diaplikasikan pada isu-isu etis dalam keseharian kerja. Beberapa persoalan etis tersebut terkait dengan akurasi dan verifikasi (accuracy and verification), independensi dan alegiansi (independence and allegiances), desepsi dan fabrikasi (deception and fabrication), citra grafis dan manipulasi citra (graphic image and image manipulation), sumber dan kerahasiaan (sources and confidentiality), kondisi khusus (special situations), dan etika yang melintasi jenis-jenis media (ethics across media types).

Sementara itu, kelompok Society of Professional Journalist telah mengembangkan prinsip-prinsip dalam penulisan berita untuk dijadikan pedoman oleh anggotanya (McBride dan Rosenstriel, 2014). Terdapat 3 prinsip utama dalam pedoman kelompok jurnalis ini yaitu: (1) mencari kebenaran dan melaporkan sepenuhnya (seek truth and report it as fully as possible); (2) bertindak mandiri (act independently); dan (3) meminimalkan kerusakan (minimize harm). 
Terkait prinsip mencari kebenaran dan melaporkan sepenuhnya (seek truth and report it as fully as possible), jurnalis diminta untuk melakukan tindakan sebagai berikut: (1) menginformasikan diri sendiri secara berkelanjutan sehingga pada gilirannya nanti bisa menginformasikan, melibatkan dan mendidik publik dengan cara yang jelas dan persuasif pada isu-isu yang signifikan; (2) jujur, adil dan berani dalam mengumpulkan, melaporkan dan menafsirkan informasi secara akurat; (3) memberikan suara bagi yang tidak mempunyai suara; dan (4) memegang tanggung jawab secara kuat. Pada prinsip bertindak mandiri (act independently), jurnalis diminta untuk melakukan hal-hal sebagai berikut: (1) menjaga secara tegas esensi peran pelayanan pers bebas memainkan perannya di masyarakat terbuka; (2) mencari dan mendiseminasikan perspektif yang bersaing tanpa menjadi terpengaruh secara tidak proporsional oleh pihak yang akan menggunakan kekuasaan atau posisi untuk melawan kepentingan publik; (3) menjaga kebebasan asosiasi dan aktivitas yang bisa mengkompromikan integritas atau merusak kredibilitas jurnalis; dan (4) mengetahui bahwa keputusan etika yang baik mempersyaratkan tanggung jawab yang diperkuat melalui kolaborasi

Terkait prinsip meminimalkan kerusakan (minimize harm), jurnalis diminta untuk melakukan hal-hal sebagai berikut: (1) berempati pada orang-orang yang dipengaruhi oleh tindakan jurnalis; (2) memperlakukan sumber, subjek dan kolega sebagai manusia yang butuh dihormati dan dihargai, tidak semata-mata alat untuk tujuan kegiatan jurnalistik; dan (3) mengetahui bahwa pengumpulan dan pelaporan informasi bisa menyebabkan kerusakan atau ketidaknyamanan, tetapi menyeimbangkan hal-hal negatif itu dengan memilih alternatif-alternatif yang memaksimalkan tujuan jurnalis untuk menyampaikan kebenaran.

Kode etik tersebut akan efektif ketika jurnalis mengetahui dan menggunakannya dalam melaksanakan pekerjaan. Hal ini penting 
karena jurnalis mempertaruhkan kredibilitasnya dalam publikasi informasi ke publik. Arti penting pemenuhan standar etika ini karena jurnalis akan mencapai tujuan untuk: (1) dapat dipercaya, akurat, jujur, independen dan memenuhi janji; (2) menghormati dan sensitif terhadap standar dan selera komunikasi; (3) memiliki penghargaan yang tinggi kepada privasi personal; (4) memperlakukan orang dengan sopan dan tata krama; (5) bersikap adil dan tidak memihak; (6) memperhatikan kelengkapan dan konteks dari fakta dan opini yang dipakai dalam berita; (7) mau mengakui dan mengoreksi kesalahan; (8) mendengarkan pertanyaan dan keluhan publik; (9) berusaha memberikan yang terbaik dalam setiap pekerjaan; dan (10) mempertimbangkan kepentingan publik dalam menentukan keputusan (Rolnicki, Tate dan Taylor, 2015).

\section{Ancaman pada Kode Etik Jurnalistik Klasik}

Berbagai nilai baik dalam Kode Etik Jurnalistik tersebut apabila bisa diaktualisasikan secara maksimal oleh para jurnalis di era disruptif sekarang ini akan bisa menjadikan kualitas informasi yang disajikan jurnalis bisa dipercaya publik dan mampu mengatasi serbuan informasi hoaks di masyarakat melalui berbagai platform media baru yang ada, baik media sosial atau media online abal-abal. Hal ini disebabkan, serbuan informasi melalui teknologi baru itu telah menyebabkan terjadinya situasi seolah-olah tanpa etika.

Sebagaimana ditunjukkan Kizza (2003), keberhasilan revolusi teknologi sekarang ini cenderung menciptakan situasi-situasi yang menggoda sebagai hasil dari semakin bebasnya nilai-nilai moral individu. Ada banyak situasi baru hasil dari revolusi teknologi komputer sekarang yang menjadikan nilai-nilai dasar yang selama ini dijadikan acuan perilaku menjadi tidak relevan atau diabaikan relevansinya. 
Kajian Ward dan Wasserman (2010) menunjukkan bagaimana teknologi media baru sedang mengganti parameter terkait etika jurnalisme. Media baru dan media campuran membantu menciptakan sebuah "etika media terbuka" dan menawarkan sebuah eksplorasi pada bagaimana perkembangan ini mendorong sebuah transisi dari sebuah etika profesi tertutup menjadi sebuah etika yang memberi perhatian pada seluruh warga negara.

Sementara itu, kajian Whitehouse (2010) menekankan arti penting pembaharuan terkait kode etik media berhubungan dengan aspek privasi. Hal ini terutama disebabkan adanya kemudahan dalam mendapatkan informasi dari jaringan media sosial untuk disebarluaskan secara terbuka. Kode etik yang ada masih memungkinkan terjadinya kecurangan dan serbuan privasi terkait kebutuhan publik. Hal ini terjadi ketika tidak ada alat alternatif yang tersedia yang cukup memadai untuk mendefinisikan apa yang membentuk kebutuhan publik tersebut. Demikian halnya terkait bobot kerugian dalam tindakan terkait pada kepercayaan publik dan profesi.

Dalam terminologi Kizza (2003), kondisi sekarang ini terasa mendesak kebutuhan untuk memformulasikan hukum baru yang memperkuat serangkaian nilai-nilai dasar yang ada yang sekarang ini mengalami reduksi atau menjadi tidak relevan karena teknologi komputer. Selain itu, dirasa perlu untuk mengkonstruksi sebuah model konseptual baru dimana hukum baru bisa diaplikasikan dengan sukses. Satu hal yang tidak kalah penting untuk dilakukan sekarang ini adalah melakukan kampanye edukasi masif pada publik untuk mengingatkan agar waspada terhadap perubahana lingkungan yang sedang terjadi dan dampaknya pada nilai-nilai dasar yang kita miliki.

Dengan mencermati hal tersebut, pertanyaan yang bisa diajukan adalah apakah peraturan hukum yang kita miliki terkait interaksi dalam dunia maya semacam Undang-undang Informasi dan 
Transaksi Elektronika (ITE) masih relevan dengan praktek komunikasi dalam dunia maya yang ada sekarang? Bagaimana halnya dengan praktek yang terjadi dalam dunia media massa kita? Apakah Undang-undang Pers dan Undang-undang Penyiaran yang kita miliki masih relevan dengan ekosistem komunikasi massa mutakhir? Apakah berbagai pedoman dan panduan profesi dalam Kode Etik Jurnalistik yang ada saat ini masih relevan dengan praktik jurnalistik yang sekarang berlangsung di dunia nyata dan dunia maya?

Tampaknya segenap pemangku kepentingan (stakeholders) dalam ekosistem komunikasi massa perlu duduk bersama untuk mendiskusikan berbagai perkembangan yang terjadi dan untuk mendapatkan titik terang strategis perilaku bermedia kita di masa depan, baik pada era disrupsi maupun sesudahnya, yang bermanfaat bagi perkembangan, dan kemajuan industri media nasional kita, maupun bagi publik yang dilayaninya.

\section{Penutup}

Era disrupsi yang ditandai dengan kemajuan pesat teknologi berbasis internet dan digital ini memberikan tantangan baru pada bisnis dan perilaku jurnalisme media konvensional. Performansi isi berkualitas tinggi dalam praktek jurnalistik akan menjadi penyelamat kehidupan industri media konvensional dari gerusan disrupsi teknologi tersebut. Kepatuhan dan ketaatan pada Kode Etik Jurnalistik yang ada menjadi sebuah keharusan untuk menciptakan performansi semacam itu. Hal ini disebabkan publik masih menaruh harapan akan kepercayaan isi media sebagai basis penting dalam menanggulangi banjir bandang hoaks di media sosial.

Akan tetapi, kita juga harus realistik menyikapi kondisi yang ada saat ini. Perilaku bermedia dalam jagad maya telah menciptakan ancaman serius bagi eksistensi kode etik jurnalisme jagad nyata. 
Hal itu disebabkan perilaku pengguna media baru yang ada telah menjadikan nilai-nilai etika bermedia yang selama ini dipercaya menjadi seolah-olah kehilangan fondasi dan eksistensinya. Apakah semua pranata tersebut masih relevan dengan ekosistem komunikasi massa yang sekarang kita hadapi? Perlu diskusi dengan semua pemangku kepentingan yang ada untuk menjawab pertanyaan ini.

\section{Referensi}

Adam, G. Stuart. (2006). "Notes Towards A Definition of Journalism”. In G. Stuart Adam and Roy Peter Clark (Editors), Journalism: The Democratic Craft. New York: Oxford University Press: 344-370

Asi. (2021). "Bantu Pemerintah Lawan Berita Provokatif: Ayo, Laporkan Joaks Corona Supaya Pelaku Dihukum Berat". Rakyat Merdeka (6 Februari. 2021)

Azzahra, Tiara Aliya. (2021). "Polri Tangani 352 Hoax terkait COVID-19 Sepanjang 2020". Detik.Com (5 Februari 2021) diakses dari https://news.detik.com/berita/d-5362961/polri-tangani-352-hoax-

terkait-covid-19-sepanjang-

2020?_ga $=2.116918022 .1222882446 .1612532059$ -

720428074.1612532059 pada 05/02/2021/20.35 wib

Kizza, Joseph Migga. (2003). Ethical and Social Issues in the Information Age (2 ${ }^{\text {nd }}$ edition). New York: Springer-Verlag New York Inc.

Kovach, Bill dan Tom Rosenstiel. (2004). Elemen-elemen Jurnalisme: Apa yang Seharusnya Diketahui Wartawan dan yang Diharapkan Publik. Jakarta: Institut Arus Studi Informasi dan Kedutaan Besar Amerika Serikat

McBride, Kelly and Tom Rosenstiel. (2014). "New Guiding Principles fior a New Era of Journalism". In Kelly McBride and Tom Rosenstiel (Editors), The New Ethics of Journalism. Thousand Oaks: Sage Publications Inc.: 1-6

Rolnicki, Tom E., C. Dow Tate and Sherri A. Taylor. (2015). Pengantar dasar Jurnalisme (Scholastic Journalism). Jakarta: Prenadamedia Group Schwab, Klaus. (2019). Revolusi Industri Keempat. Jakarta: Gramedia

Sunarto, Nurul Hasfi dan Amida Yusriana. (2020). Monograp Esensi Kepemimpinan Jurnalis Wanita di Media Pada Era 4.0. Semarang: Alinea 
Steele, Bob. (2014). "Journalism Ethics Then and Now". In Kelly McBride and Tom Rosenstiel (Editors), The New Ethics of Journalism. Thousand Oaks: Sage Publications Inc.: vii-ix

Ward, Stephen J.A. (2009). "Journalism Ethics". In Karin Wahl-Jorgensen and Thomas Hanitzsch (Editors), The Handbook of Journalism Studies. New York: Routledge: 295- 309

Ward, Stephen J.A and Herman Wasserman. (2010). Towards an Open Ethics: Implications of New Media Platforms for Global Ethics Discourse. Journal of Mass Media Ethics. Exploring Questions of Media Morality. Volume 25

275-292. https://doi.org/10.1080/08900523.2010.512825

Whitehouse, Ginny. (2010). Newsgathering and Privacy: Expanding Ethics Codes to Reflect Change in the Digital Media Age. Journal of Mass Media Ethics. Volume 25 (4): 310-327. Https://doi.org/10.1080/08900523.2010.512827

Widjaya, Yunizafira Putri Arifin. (2018). Hati-hati Baca Berita, Dewan Pers Catat 43.300 Media Online Tidak Terdata. Dalam https://www.liputan6.com/news/read/3528505/hati-hati-baca-beritadewan-pers-catat-43300-media-online-tidak-terdata akses 29/03/2021/19.30 wib

\section{Profil Penulis}

Sunarto menyelesaikan pendidikan program Sarjana di Universitas Diponegoro (1990), dan program Master (2000), serta program Doktor (2007) di Universitas Indonesia. Dosen tetap Program Magister IImu Komunikasi Universitas Diponegoro. Menekuni bidang Komunikasi Massa dan Gender baik dalam riset maupun pengabdian kepada masyarakat. Buku yang telah diterbitkannya adalah Televisi, Kekerasan dan Perempuan (2009), Analisis Wacana: Ideologi Gender Media Anak-anak (2000). Artikel berjudul "Literasi Media dan Dominasi Maskulin di Televisi" dalam buku Literasi Media \& Kearifan Lokal: Konsep dan Aplikasi (2012), "Generasi X dan Koran Era Disrupsi” dalam buku Esai Pengalaman Merangkai Asa untuk Media Massa (2020), dan "Kepemimpinan Androgini Wanita Di Era Pandemi" dalam buku Perempuan \& Pandemi Covid-19 (2021). 